\title{
64- Evaluation of disability in Carson McCullers' The Ballad of the Sad Café ${ }^{1}$
}

\section{F. Gül KOÇSOY²}

\begin{abstract}
APA: Koçsoy, F. G. (2021). Evaluation of disability in Carson McCullers' The Ballad of the Sad Café. RumeliDE Dil ve Edebiyat Araşturmalart Dergisi, (25), 1055-1063. DOI: 10.2900o/rumelide.1036616.
\end{abstract}

\begin{abstract}
This study enquires into Carson McCullers' The Ballad of the Sad Café (1951) in terms of Disability Studies. McCullers problematizes the disabled body as 'the other/marginalized' by introducing a disabled/freak character, Cousin Lymon, who is a hunchbacked dwarf and an outcast; he is mischievous, talkative and intriguer. Thus, she opens questions about the characterization of disabled people employing a setting of the gothic/grotesque American south where people are prejudiced against the disabled. At the beginning, Lymon is pitiful/pitied, desires to be liked and socially accepted. Later, he asserts his personality, benefits from his vulnerability and proves his multidimensional and manipulative character. He takes advantage of Miss Amelia's attraction to him. He is not a role model, moreover, he is an evil force and a grotesque figure. He abandons her for the sake of her enemy, her husband, whom she dismissed from her house long before. He invalidates her reliance on him and leaves her alone. He sets everybody in the neighborhood aback, because she had helped him in his most needy time. In this way, McCullers de/reconstructs the prejudice and stereotyping against disabled people, seeming to confirm the southern point of view. She blurs the line between the concepts and perceptions of disability and non-disability.
\end{abstract}

Keywords: Carson McCullers, The Ballad of the Sad Café, disability studies, grotesque, American south

\section{Carson McCullers'ın Küskün Kahvenin Türküsü adlı eserinde engelliliğin ele alınışı}

Öz

$\mathrm{Bu}$ çalışma, Carson McCullers'ın Küskün Kahvenin Türküsü (1951) adlı nuvelini Engellilik Çalışmaları açısından incelemektedir. McCullers engelli bedeni, kambur bir cüce ve toplum dışı biri olan Kuzen Lymon gibi engelli/ucube bir karakteri işleyerek ‘öteki/uç’ olarak sorunsallaştırır; Lymon fesat, konuşkan ve hilekârdır. İnsanların engellilere karşı önyargılı olduğu gotik/grotesk Amerikan güneyini mekan olarak kullanıp engelli kişilerin karakterlerinin incelenmesi üzerine sorular sorar. Başta, Lymon acınası/acınan biridir, sevilmeyi ve toplumsal anlamda kabul görmeyi arzular. Daha sonra, kişiliğini öne çıkarır, kırılganlığından faydalanır, çok boyutlu ve çıkarcı karakterini ortaya koyar. Miss Amelia'nın ilgisini avantaj olarak kullanır. Örnek alınacak biri değildir, dahası kötü bir güç kaynağı ve grotesk bir kişidir. Amelia'nın düşmanı olan ve çok önceden evden kovmuş olduğu kocası hatırına Amelia'yı terkeder. Onun güvenini boşa çıkarır ve yapayalnız bırakır. Civardaki herkesi şaşkına uğratır çünkü Amelia ona en çok yardıma muhtaç olduğu zamanında yardım etmiştir.

This article is the extended version of the paper with the same title presented at 3rd IBU-ICSSH 2021 Conference in Skopje, North Macedonia between 10-12 June 2021.

Doç. Dr., Frrat Üniversitesi, İnsani ve Sosyal Bilimler Fakültesi, Batı Dilleri ve Edebiyatları Bölümü, İngiliz Dili ve Edebiyatı ABD (Elazığ, Türkiye), fgulkocsoy@firat.edu.tr, ORCID ID: 00oo-00o2-7813-8961 [Araştırma makalesi, Makale kayit tarihi: 02.09.2021-kabul tarihi: 20.12.2021; DOI: 10.29000/rumelide.1036616] 
McCullers güneyli bakış açısını benimsemiş gibi gözükerek engellilere karşı olan önyargı ve basmakalıp inanışları önce yapıbozuma uğratır, sonra yeniden yapılandırır. Engellilik ve engelli olmama durumuna dair kavramlar ve algılar arasındaki çizgiyi bulanıklaştırır.

Anahtar kelimeler: Carson McCullers, Küskün Kahvenin Türküsü, engellilik çalışmaları, grotesk, Amerikan güneyi

Dichotomy is based on differences rather than similarities in the formation of societal norms and people's ethnicity, race and culture are the primary factors in designing the established values. We/they dichotomy comprises the differences like physical appearance within the dominant culture. 'We' denotes 'the normal' or 'the beautiful' while 'they' connotes the reverse. Healthy (normal)/unhealthy (abnormal), beautiful/ugly and abled/disabled binary oppositions are associated with perversity, transgression, disgracefulness and moral looseness in many societies. This is, of course, a prejudice and social othering, and the emergence of Disability Studies in the late 2oth century marks the questioning of this wrong point of view and discrimination toward the disabled.

Disability Studies emphasizes the particularity of the disabled body/soul and social construction of normalcy/disability in psycho-social terms. According to Davis, "An impairment involves a loss or diminution of sight, hearing, mobility, mental ability, and so on. But an impairment only becomes a disability when the ambient society creates environments with barriers - affective, sensory, cognitive, or architectural" (2002:41). Thus, it becomes obvious that disabled people are an oppressed minority group, subject to segregation, and societies generate a concept of disability by themselves. In fact, while impairment is a physical situation, disability is a social construction; the impaired people are not 'the other' to be pitied, stigmatized or disregarded but are only different. Disability studies "involves scrutinizing not bodily or mental impairments but the social norms that define particular attributes as impairments, as well as the social conditions that concentrate stigmatized attributes in particular populations. (Minich,2016) It follows a deconstructive method and "one of the major tasks of this new field is to determine why this 'fact' of disturbance exists, is accepted, and is promulgated" (Davis, 1999:504). It also focuses on the needs and rights of the disabled.

The disabled people in Western culture are reflected as monsters: "the notion of monster is necessarily related to that of disability" (Stiker,1999:72) and "[t]he person who is afflicted is made to bear the burden of sin, the burden of wrongdoing" (Stiker,1999:30). In the same vein, the predominant ethos depicts the "defectives as a repulsive, dangerous, and costly menace to society" (Pernick, 1996:143). In the early history of the United States, a baby born disabled was often left to die, for example. When evil is made visible, it is easier to understand it, and attributing the cause of disabilities to evil can be seen as justifiable. Quicke states:

"there are, latent to the dominant culture, ideas about handicap and disability from an earlier period which still have considerable force. An example is the notion, which runs through the history of Western civilization and is legitimated by various religious teachings, that disability indicates possession by the devil or by an evil force, or is the outcome of evil doing" (1985:3).

Thus, deformity of the body refers to the deformity of the soul in many western societies.

In a similar way, most, most fiction presents disability as catastrophic, sad or a burden for the person affected; it is a burden for those around them, too. Evil stereotypes arouse the feeling of the uncanny, repulsion or hatred, and they have extraordinary powers like intelligence, rhetoric or supernatural powers to intuit or foresee. Literature, as it shapes culture and is shaped by culture, has an important 
place in the representation of disabled people. Traditional children's fiction often portrays giants and giants and disabled characters as evil because they are physically impaired. As a cliché, disabled people are not protagonists; they are secondary, supporting/complementary characters, antagonists or confidants helping the action flourish. At the end, they are the monsters/villains/victims of the story or dead or must be killed in order not to give harm to the 'normal' people around. Garland-Thomson writes that in literature "disabled characters with power virtually always represent a dangerous force unleashed on the social order,... Because these characters operate as embodiments of an unnamed, profound peril, the narrative resolution is almost always to contain that threat by killing or disempowering the disabled character" (2017:36). In this frame, the gothic genre is a proper site to represent and reflect the established values of the society on disability. "No other genre so welcomes culturally defined 'sickness' and horror as the gothic" (Gross,1989:59). It emphasizes the disabled characters' visibility as evil ones and presents them as grotesque figures, arousing loathsome and threatening effect on the reader. "The presentation of physical disability in the Gothic is a direct response to the long-held habit of Western culture to define the human norm, then to construe the non-normative as dangerously close to being non-human. While Gothic writers have often indulged in 'othering' to create a fear of the unknown across the boundaries of race, nationality, or ethnicity, these characters are generally still painted as mostly human 'others' “(https://epublications.marquette.edu/gothic_deformity/ 2021). In the same way, in gothic literature, "a fascination with disease and decomposition represents a liberation from the confines of beauty" (Bayer-Berenbaum,1982:28); 'confines of beauty' means that the gothic by its nature challenges the established notions or images of the body. The traditional gothic binary of health/illness finds its projection in the disabled body. Disability Studies deconstructs this duality, not making illness ideal but normalizes and equalizes it as an established category.

Southern gothic as a subgenre of the gothic emerged in the early $19^{\text {th }}$ century taking its subject from the grotesque setting and characters from the American south. An isolated area from the other states, the south has been a major region of the gothic/the southern gothic, because it has its own peculiar culture and history: the myths, folklore, beliefs and legends are productive for the twisted characters, violence, the uncanny and the grotesque. It is a proper place for gothic possibilities: "The American South, with its legacy of profound social and economic problems, became a major focus and source of American literature in the twentieth century, and the principal region of American Gothic" (Crow,2009:124). The people have warped beliefs and may behave in irrational ways. They have a prejudice against outsiders and others. As a conservative rural society, the southern people regard disability in traditional terms disregarding its precariousness and fragility; they see the disabled people as 'the other', having negative character traits by stereotyping them as dangerous, disturbing and fearful gothic selves. The disabled is burdened with a public identity comprising stigma and moral corruption.

Carson McCullers (1917-1967) is categorized as a late modernist searching for meaning and questioning past values and her fiction has been described as southern gothic. Misfits, eccentric or flawed characters and grotesque elements can be observed in many of her works. She employs them to depict and criticize the mainstream southern point of view toward the disabled, which is hostile and prejudiced. She aims at shocking the reader by seeming to consolidate this view. Her southern roots contribute to her portrayal of the southern cast of mind truthfully. She questions the disability phenomenon in The Ballad of the Sad Café (1943), which tells how a disabled person asserts his personality to find a place to stay, how he domineered a dominant woman, makes her convert her house into a café and at last deserts her when she needs absolute help. In this frame, this article aims to prove that she amalgamates her modernism with her ideas about disability, which anticipate and overlap the $20^{\text {th }}$ and $21^{\text {st }}$ century Disability Studies. 
The beginning of the story is traditional; the place and the characters are introduced in a realistic tone. The point of view of the narrator is objective but narrow-minded and traditional so that the intrusion of the author/narrator is seen. The nouvelle opens with the description of an isolated and ordinary southern town in Georgia. In it, there is a derelict building. McCullers describes it with grotesque overtones:

\begin{abstract}
"The largest building, in the very center of the town, is boarded up completely and leans so far to the right that it seems bound to collapse at any minute. The house is very old. There is about it a curious, cracked look that is very puzzling until you suddenly realize that at one time, and long ago, the right side of the front porch had been painted, and part of the wall - but the painting was left unfinished and one portion of the house is darker and dingier than the other. The building looks completely deserted. Nevertheless, on the second floor there is one window which is not boarded; sometimes in the late afternoon when the heat is at its worst a hand will slowly open the shutter and a face will look down on the town. It is a face like the terrible dim faces known in dreams - sexless and white, with two gray crossed eyes which are turned inward so sharply that they seem to be exchanging with each other one long and secret gaze of grief...you might as well walk down to the Forks Falls Road and listen to the chain gang" (McCullers, 2021).
\end{abstract}

The building was once a store, and on it, there was a house. The owner is Miss Amelia Evans who is also lonely and now old. In her youth, she is independent, gawky and masculine. She is good at wrestling, boxing, shop-keeping, doctoring, bootlegging and carpentry, seemingly in need of nobody. Amelia is like a man; "indeterminately gendered body surfaces throughout her fiction ..." (Adams,1999:559) A dismal character, she is not sociable and talkative. She is advantageous, sues people on minor problems and gets money. She is the most powerful and wealthy person in the town. She is skillful; she works at a distant place in making the best liquor, prepares chitterlings and sausages and grape molasses. With her, McCullers "provides a more obvious example of female ugliness as dissent" (GleesonWhite,2003:51). She is different from the ordinary typical southern women and can be seen as a grotesque figure. "Her marriage had been unlike any other marriage ever contracted in this county - it was a strange and dangerous marriage, lasting only for ten days, that left the whole town wondering and shocked. Except for this queer marriage, Miss Amelia had lived her life alone. Often she spent whole nights back in her shed in the swamp, dressed in overalls and gum boots, silently guarding the low fire of the still" (McCullers, 2021). Her marriage was to Marvin Macy, who ruined many village girls, and who attempts a respectable life when he falls in love with her. The relationship is strange, for he is a very handsome man. He signs a contract leaving all his possessions to her but is cheated by her. The marriage is unconsummated; he again becomes violent, a robber, full of revenge and is sent to prison. After he leaves, she continues her life inheriting all goods and presents from him, but hating him without reason until a disabled person, Lymon Willis comes.

Lymon's arrival has an ominous sign: "While they were waiting there, a dog from one of the houses down the road began a wild, hoarse howl that continued until a voice called out and hushed him" (McCullers, 2021). McCullers depicts Lymon from the point of view of the townspeople; a person with physical deformities as the other/outcast is epitomized by the character of him. She portrays a miserable man coming at night to Amelia's house:

"The man was a stranger, and it is rare that a stranger enters the town on foot at that hour. Besides, the man was a hunchback. He was scarcely more than four feet tall and he wore a ragged, dusty coat that reached only to his knees. His crooked little legs seemed too thin to carry the weight of his great warped chest and the hump that sat on his shoulders. He had a very large head, with deep-set blue eyes and a sharp little mouth. His face was both soft and sassy - at the moment his pale skin was yellowed by dust and there were lavendar shadows beneath his eyes. He carried a lopsided old suitcase which was tied with a rope" (McCullers,2021). 
This depiction is stereotyped; despite pitiful, he is repellent and grotesque. He gives no background information about himself to the men around, claiming to be distant kin of her. "His hands were like dirty sparrow daws and they were trembling. The bag was full of all manner of junk - ragged clothes and odd rubbish..." (McCullers,2021) With an exact southern view, his corporeal malformation is caricaturized, being out of the 'normal'. It is a degrading description, focused on physicality.

Although he shows her a photograph of two children, Amelia cannot recognize them. While he is waiting for her answer " $[t]$ he hunchback stood with his bag open on the bottom step; he sniffled his nose, and his mouth quivered. Perhaps he began to feel his dismal predicament. Maybe he realized what a miserable thing it was to be a stranger in the town with a suitcase full of junk, and claiming kin with Miss Amelia. At any rate he sat down on the steps and suddenly began to cry" (McCullers,2021). He is again portrayed as a pitiful creature in need of compassion and help. In fact, he tries to benefit from his impaired situation and he is more advantageous than Amelia.

After scrutinizing Lymon for some time, Amelia decides to take him into her house. It is clear that the admission does not spring from her philanthropic attitude. Whether she falls in love with him or quickly thinks about him as a company, who will share her loneliness, she accepts him into her house not as a guest but a constant family member. The men around become surprised, for she never invites anyone to her house.

Cousin Lymon's disability is the central place in the work. She knows that a 'normal' man in the eyes of the townspeople will arouse doubt and indignation, but nobody suspects of a disabled man as her partner. This means that she needs a friend or a companion although she seems powerful. Even a 'hunchback dwarf' will serve. On the other hand, Lymon is not as an easy-going person as he seems. After settling the house, "[t]he hunchback came down slowly with the proudness of one who owns every plank of the floor beneath his feet" (McCullers, 2021). With his ability to affect people and to talk he begins to make Amelia do everything he wants. He now looks clean, healthy and happy in new clothes.

The narrator, like a typical southern person despises him: "Each night the hunchback came down the stairs with the air of one who has a grand opinion of himself. He always smelled slightly of turnip greens, as Miss Amelia rubbed him night and morning with pot liquor to give him strength. She spoiled him to a point beyond reason, but nothing seemed to strengthen him; food only made his hump and his head grow larger while the rest of him remained weakly and deformed" (McCullers,2021). He hops around, making jokes among people. She cannot see that he exploits her because of her affection.

He is challenging and still grotesque: "He regarded each person steadily at his own eye-level, which was about belt line for an ordinary man. Then with shrewd deliberation he examined each man's lower regions - from the waist to the sole of the shoe. When he had satisfied himself he closed his eyes for a moment and shook his head, as though in his opinion what he had seen did not amount to much. Then with assurance, only to confirm himself, he tilted back his head and took in the halo of faces around him with one long, circling stare" (McCullers,2021). It is clear that he knows much about people, and he is conceited. In fact, he despises and mocks them. Here, McCullers draws attention to the point that the disabled are like the other 'normal' people, having character defects, and not ideal people. For instance, in his hand, he holds the snuffbox which belonged to her father and very special for her. One of the men asks: “"Yes, what is it, Peanut?" The hunchback looked up quickly and sharpened his mouth to speak. "Why, this is a lay-low to catch meddlers" (McCullers,2021). She gives many special things to him; for example she gives her father's snuff-box, which she never allows anyone to touch. She shares every secret 
with him except her marriage. McCullers describes him as an intelligent, witty and cunning person. He is gossipy and curious about people's secrets and defects, often making them clash. "The hunchback was a great mischief-maker. He enjoyed any kind of to-do, and without saying a word, he could set the people at each other in a way that was miraculous. It was due to him that the Rainey twins had quarreled over a jacknife two years past,... He nosed around everywhere, knew the intimate business of everybody, and trespassed every waking hour" (McCullers,2021).

Lymon knows how to cheat or convince people. He is selfish and defective both physically and morally and assumes himself high. He chats with everybody and entertains them, but meanwhile analyzes their characters in order to get on well with and manage them. He manipulatively asks questions to them to learn about their pasts, families and their relationships. He has communication skill and soon, many people gather around him. Here, it is clear how he got Amelia to accept him in her house for good. They are a grotesque pair, and he uses/abuses her for his comfort.

There is a great difference between his first appearance and that of now but he is still grotesque: "He did not wear trousers such as ordinary men are meant to wear, but a pair of tight-fitting little knee-length breeches. On his skinny legs he wore black stockings, and his shoes were of a special kind, being queerly shaped, laced up over the ankles, and newly cleaned and polished with wax. Around his neck, so that his large, pale ears were almost completely covered, he wore a shawl of lime-green wool, the fringes of which almost touched the floor" (McCullers,2021). He now walks with his strut. He is challenging and shows that his place is confirmed because he knows she is behind him. The narrator's point of view is scathing and cynical; the narrative voice imposes the reader to be critical about him and not to accept his comfortable life as deserved. McCullers adopting the southern cast of mind, judges him ironically: he is disabled and has a defective character, so he does not deserve to live in such a luxury.

McCullers employs the disabled Lymon to show that his existence signifies his capacity to direct a powerful woman. He calls her as Amelia, without 'Miss'. He not only settles the house but starts to transform it. She converts her store into a café upon his desire. She begins selling liquor and meal in the evenings. She concedes what he asks of her. She becomes calmer, more generous and good-tempered. With his wish, she allows the men to drink their liquor in the store instead of on the porch or in the street. The men are unable to understand what kind of a relationship they share and how she breaks her habits and rules. "[T]he uncommon romance that develops between the manly giantess Miss Amelia and the effeminate little hunchback Cousin Lymon" (Clark,1975:164) is perplexing. The changes both in the place and in Amelia's attitudes are perplexing, too. Assuming himself high Lymon prances around the café. "The hunchback's arrival thus affects a series of changes that implicate not only the two people involved but the town as a whole, for with the Café comes society and with society a newfound sense of belonging and self-worth..." (Millar,2009:102) Although their relationship is absurd and an example of black humor, everybody seems satisfied, which may be regarded as the southern peoples' hypocrisy. The people enjoy the facilities in the café's atmosphere. The changes coming with him signify the power of a disabled person. In this frame, McCullers hints that disabled people should not be pitied; they are only different and may have powerful characteristics. On the other hand "[he] had a deep fear of death. And Miss Amelia would not leave him by himself to suffer with this fright. It may even be reasoned that the growth of the café came about mainly on this account..." (McCullers,2021); for this reason, she has to leave the café open until midnight.

Lymon becomes a source of amusement among the people with his cheerful, talkative humor and charismatic personality because for they work hard and for long hours except going to church on 
Sundays, they see that they need to come together only for pleasure. He with his foresight sees the need and the café as a social center is established. Everybody feels to behave politely to one another and a different kind of socialization is experienced thanks to him. Amelia looks uncertain and uncomfortable about all this, but either out of love or helplessness, she accepts every request of him. She even buys a piano upon his wish. Amelia nearly becomes his servant; he scrambles on her back- she carries himwhen they go to the swamp. She cannot see that he exploits her. Giving no information about his background or age Lymon deceives her by ingratiating himself into her and later into the townspeople's favor.

Marvin, after six years is out of prison. When he comes, Lymon is very curious about him, for he is a stranger and follows him wherever he goes. "Aside from this inborn curiosity, the hunchback took a great interest in robbers and crimes of all varieties" (McCullers,2021). He sees that Amelia is very angry with him and his curiosity increases. She on the other hand, does the activities that improve her strength in case Marvin comes and tries to fight with her. She seems to love Lymon more than ever. "He and the man stared at each other, and it was not the look of two strangers meeting for the first time and swiftly summing up each other. It was a peculiar stare they exchanged between them, like the look of two criminals who recognize each other" (McCullers,2021). It is as if their common wicked characters find each other. Lymon begins to follow him everywhere although his health is fragile.

Marvin comes to Amelia's premises and sits in the café with the other men. Lymon tries hard to ingratiate himself with him by wiggling his large ears, fluttering his eyes or dancing, but Marvin pays no attention to him.. “ 'Is the runt throwing a fit?' he asked, and when no one answered he stepped forward and gave Cousin Lymon a cuff on the side of his head. The hunchback staggered, then fell back on the ground. He sat where he had fallen, still looking up at Marvin Macy, and with great effort his ears managed one last forlorn little flap" (McCullers,2021). It is surprising that Amelia, though Lymon is dear to her cannot respond. She is afraid of Marvin now and feels broken when she sees that Lymon flatters him. She is sorry to see that the two are going to be friends. He declares that he will stay with them, upon which Amelia is again silent. She tolerates many things that she never tolerated before. The reason is that she fears being left alone. She trusts Lymon greatly until he becomes a fan of Marvin. She is helpless and unsuccessful to turn him again to herself. Amelia has always protected him against people, but now she sees this scene with terror but does nothing. Lymon is also shocked and annoyed. Of course Marvin challenges Amelia by beating him. She does not tell Lymon the truth that he is her husband, increasing his curiosity. At last, Marvin accepts him as a company. Lymon carries no gratitude or faith for the people who help him and who ask only for love and company. It is not difficult to understand Lymon's motives to change his position as Amelia's friend to Marvin's slavish company when his character is thought. Lymon becomes insolent; "he crossed his eyes and aped her gestures in a way that made her appear to be a freak" (McCullers, 2021), and she becomes more reproachful to Lymon.

She ties a punching bag to a tree to practice for a fight with Marvin. The fight between the two is organized. The townspeople never intrude: they wait for it impatiently and excitedly as a typical grotesque community. Lymon leaves painting the house unfinished, because he is sure that Marvin will win and they will leave her. He watches the fight from his perch on the counter of the café. For some time neither is defeated, but when they begin wrestling, she pins him. Upon this, "the hunchback sprang forward and sailed through the air as though he had grown hawk wings. He landed on the broad strong back of Miss Amelia and clutched at her neck with his clawed little fingers" (McCullers,2021). She has to set him free and is beaten because of Lymon. Here, Lymon shows his defiled, merciless and ungrateful nature at its best and proves himself a miscreant. 
Lymon and Marvin pillage every valuable thing, her goods and the café, even her jars of jam, carve terrible words onto the tables, dismantling her whiskey still before leaving. The two give harm to everything she cherishes, pour syrup all over the kitchen floor. Lymon ironically deserts her with her adversary when she most needs him. Thus, their "mutual codependency" (Millar,2009:97) is finished. While Lymon " is a man loved without sex, a child acquired without pain and a companion which her limited personality finds more acceptable than a husband or a child” (Millichap,1973:335) he betrays her severely, and she becomes a victim subjected to physical and/or emotional violence. The neighbors never protect or console her for her unjust defeat, and she sobs profoundly. She feels offended and angry with everybody. At the end, it seems justice is done, because Amelia was not a good person. The people can only listen to the songs of the chain gang that is composed of twelve prisoners. Their song is sad as if they are singing or lamenting for Amelia, and they console themselves and her. She, for years, tries to overcome her defeat, Lymon's treachery and unfaithfulness. She boards up the building and becomes a recluse full of bitterness. This is what he has made to her as a transforming and manipulative character. "Involuntary deviance, stigmatized master status, management of a spoiled identity, ... are some of the most systematic representations of disability as a problem..." (Titchkosky,2000:200); the traditional approach to the disabled seems justified. About Lymon "[t]here were rumors that Marvin Macy used him to climb into windows and steal, and other rumors that Marvin Macy had sold him into a side show" (McCullers,2021). Again the town becomes as it was, dreary and lonesome.

McCullers deals with the physically deformed and spiritually corrupted in a melting pot, in line with the typical southern view. She first portrays a typology of the disabled in the same vein of the traditional gothic perspective, and the townspeople's view of Lymon is but stereotyping. Her language, the narrator's point of view and the story itself are designed to reflect the southern cast of mind towards the disabled. She then deconstructs his disability: he is accepted as a 'normal' man, and the disabled are not the people to be pitied, marginalized or otherized in their view. McCullers in the vein of disability studies, prescribes that disabled people are like the other people in society; they should not be ostracized, pitied or idealized as angel-like figures. They should be treated as normally as anybody; they are only different. Her implication here fits into the approach of the Disability Studies, and her method of reconstructing and then deconstructing disability makes her a modernist as well as an early postmodernist writer. On the other hand, in the end, she reconstructs the traditional point of view, completing the cycle and demonstrating him/the disabled body as a morally corrupt person. She problematizes the disability phenomenon by blurring the traditional and modern beliefs about disability. She disrupts the accepted or established assumptions seeming to adopt the southern point of view.

As a late modernist, she employs a technique of disguising her messages about the disability phenomenon by adopting the southern point of view toward the disabled which has negative elements, and shocking the reader. While doing this, she also exhibits this view's narrowness, provinciality and anti-modern nature. Her technique of reflecting this bigotry about the disabled has another layer; "neither pitiable nor repulsive, neither a hero nor a symbol, but a part of the community with issues and influences like everyone else" (Northen, 2021). People must not focus on a disabled person's physicality; they are as normal as everybody else, and their character traits are independent of their bodily situation. She also proves that the disabled are exactly like other people in terms of character typology. 


\section{References}

Adams, Rachel (1999). " ‘A Mixture of Delicious and Freak': The Queer Fiction of Carson McCullers” American Literature. Vol. 71, No. 3 (September) pp. 551-583 https://www.jstor.org/stable/2902739 (28 March 2021).

Bayer-Berenbaum, Linda (1982). The Gothic Imagination: Expansion in Gothic Literature and Art. Toronto: Associated UP.

Clark, Charlene Kerne (1975). "Pathos With a Chuckle: The Tragicomic Vision In The Novels Of Carson McCullers" Studies in American Humor. (January) Vol. 1, No. 3 pp. 161-166 https://www.jstor.org/stable/42573058 (28 March 2021).

Crow, Charles L. (2009). History of the Gothic: American Gothic. Cardiff: University of Wales Press.

Davis, Lennard J. (1999). "Crips Strike Back: The Rise of Disability Studies". American Literary History. (Autumn) Vol. 11, No. 3 pp. 500-512 https://www.jstor.org/stable/490130 (28 March 2021).

Davis, Lennard J. (2002). Bending Over Backwards. New York: New York University Press.

Garland-Thomson, Rosemarie (2017). Extraordinary Bodies: Figuring Physical Disability in American Culture and Literature. New York: Columbia UP.

Gleeson-White, Sarah (2003). "A Peculiarly Southern Form of Ugliness: Eudora Welty, Carson McCullers, and Flannery O'Connor". The Southern Literary Journal. Vol. 36, No. 1 (Fall), pp. 4657 https://www.jstor.org/stable/20078381. (28 March 2021).

"Glossary of the Gothic: Deformity". https://epublications.marquette.edu/gothic_deformity/ Marquette University (30 May 2021).

Gross, Louis S. (1989). Redefining the American Gothic: From Wieland to Day of the Dead. Ann Arbor: UMI Research Press.

McCullers, Carson (1943). The Ballad of the Sad Café. https://repositorio.ufsc.br/bitstream/handle/123456789/163729/The\%20Ballad\%20of\%2othe \%20Sad\%20Caf\%C3\%A9\%20-\%20Carson\%20McCullers.pdf?sequence=1 (30 May 2021).

Millar, Darren (2009). "The Utopian Function of Affect in Carson McCullers's The Member of the Wedding and The Ballad of the Sad Café". The Southern Literary Journal. Vol. 41, No. 2 (Spring), pp. 87-105 http://www.jstor.com/stable/40593308. (28 March 2021).

Millichap, Joseph R. (1973). "Carson McCullers' Literary Ballad”. The Georgia Review. Vol. 27, No. 3 (Fall), pp. 329-339 https://www.jstor.org/stable/41398235. (8 June 2021).

Minich, Julie Avril (2016). "Enabling Whom? Critical Disability Studies Now”

Lateral: Journal of the Cultural Studies Association. Issue 5.1 (Spring) https://csalateral.org/issue/51/forum-alt-humanities-critical-disability-studies-now-minich/ (3 June 2021).

Northen,Michael (2021) https://wordgathering.syr.edu/past_issues/issue24/essays/northen.html (9 March 2021).

Pernick, Martin S. (1996). The Black Stork. New York: Oxford University Press.

Quicke, John (1985). Disability in Modern Children's Fiction. Cambridge, MA: Brookline Books.

Stiker, Henri-Jacques (1999). A History of Disability. (trans. by William Sayers) Ann Arbor: The University of Michigan Press.

Titchkosky, Tanya (2000). "Disability Studies: The Old and the New". The Canadian Journal of Sociology / Cahiers Canadiens de Sociologie. Spring, Vol. 25, No. 2 pp. 197-224 https://www.jstor.org/stable/3341823 28 March 2021. (28 March 2021). 